\title{
between two voices talking
}

\author{
Brief encounter.
}

\section{BY LAURENCE RAPHAEL BROTHERS}

$\mathrm{T}$ he alien vessel entered orbit around the Moon and maintained silence, ignoring all transmissions. The eyes of the world were fixed on the craft as a joint Russian-American mission set out to make contact.

With the voyage capsule approaching its rendezvous, the two crew members prepared for their historic encounter. NASA's Marla Pham, a specialist in languages, was charged with boarding the alien vessel. Colonel Pyotr Ulyanovich Simonov of Roscosmos remained in the capsule.

Marla hadn't mentioned anxiety attacks to the counsellor during her evaluation. The last had been years ago, before her orals. But this attack had been building ever since launch. And now, at the crucial moment, it crested. Fear filled Marla's being, rushed through her blood vessels, pulsed through her nerves. It was almost paralysing, but she forced herself to pass through the docking tube and into the unknown.

The alien's outer airlock door swung shut as Marla entered; she couldn't help shuddering as her path to safety was cut off. The tiny cramped chamber cycled to fill with air, and the inner door opened to reveal a surprisingly homely little room.

Artificial gravity: $1.0 \mathrm{G}$. Temperature: a balmy $26^{\circ} \mathrm{C}$. Appearance: dark-blue carpeting with an ornate yellow geometrical pattern. Equipment: a low wooden table in the centre of the room; a black ceramic teapot on the table, steam rising from the spout. Two off-white porcelain cups sat by the pot, hexagon patterns in faint cobalt blue glazed into the finish. Illumination came from the ceiling, which Mission Control said duplicated Sol's spectrum.

Built for humans, Marla thought.

The room was unshielded; her comm links stayed up. Overcoming a terrible moment of total paralysis, Marla cracked the seal on her helmet.

"Marla! What are you doing? Are you crazy?" Pyotr's voice buzzed in her ear.

I'm in charge of contact, she sent, texting him from a tablet on her forearm to avoid

\section{$\rightarrow$ NATURE.COM}

Follow Futures:

@ @NatureFutures

f go.nature.com $/ \mathrm{mtoodm}$ speaking out loud. Despite Pyotr's protests, despite her own fear, Marla removed her spacesuit and laid it by the airlock. She couldn't drink tea in armour, no matter how high the risk. Grabbing her tablet, Marla walked cautiously to the table and knelt down. She sniffed the air and was rewarded with the fragrant scent of trà sen lotus tea.

Vietnamese tea! Could this have been prepared just for me?

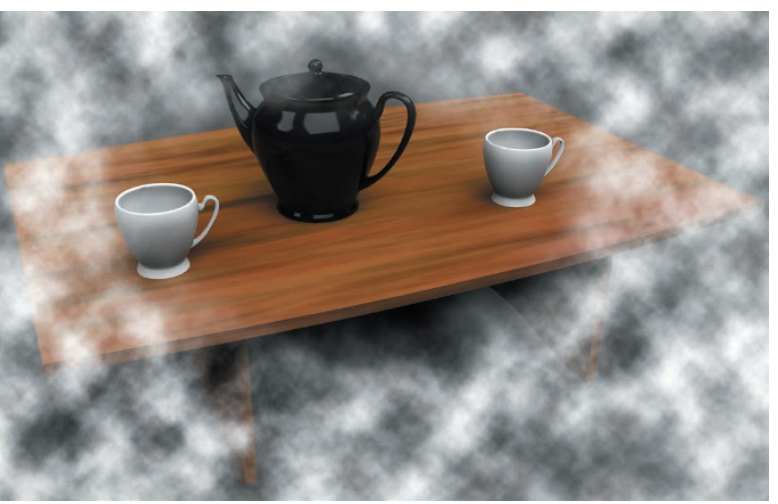

"Thank you for arranging this room," she said in English, a small tremor in her voice. "It is very comfortable."

Silence. It felt like hours but her lens display said less than a minute had passed. Suggestions from Control scrolled by in the lower field of her vision. They could tell her heart rate was 120 , but they thought it was normal nerves.

"Nothing happening," said Pyotr. "There are no signals."

At last she said in Mandarin: "I welcome you to our world."

No response.

"I greet you in friendship," she said, switching to French.

She paused.

"Nothing," said Pyotr. "You should come back."

She wanted desperately to agree but knew she'd never forgive herself if she did.

"Please answer," she said in Spanish. "You have made the long journey to our world. You must have created this room for a reason."

Still no response.

"Maybe it's just a machine," Pyotr suggested.

Yes ... perhaps this whole spacecraft is nothing more than a trap. Marla swallowed, forcing the notion away.

She switched to Vietnamese. "You must have wanted this meeting. Please -" Her voice caught in her throat.

Nothing but silence.
"Maybe it's shy," said Pyotr.

Marla bit her lip.

You might be right, she keyed on her tablet. "Ha," he said, "you think?"

She stood up and bowed.

"I'm sorry," she said. "I came to meet you. But I feel fear as well. Fear of the unknown. I understand if you hesitate to show yourself. Perhaps my appearance scares you. But it seems a shame to come all this way for nothing."

She bowed again, gathered up her suit and turned towards the airlock. Was there even a way to open the door?

"Bozhe moi! Turn round, Marla!"

Marla's fear surged up again like a geyser, blasting through her like fire and ice and shame and death. It was the hardest thing she'd ever done not to scream. Because now she knew she was not alone.

The voice came from behind her. Spoken in Vietnamese, so softly she could barely hear it.

"Wait," it whispered. "Please..."

Marla took a deep breath and turned round.

There was a shadow on the far side of the room. It was small and she couldn't see what it concealed. Marla put down the spacesuit and returned to kneel before the table, her heart hammering in her chest. She extended her hand slowly, placing it palm up on the table, feeling the blood racing, making her fingertips shudder with every beat. The shadow extended towards her. She felt a feathery delicate touch like a young fern frond tentatively exploring her hand. The shadow encompassed the teapot, and when it withdrew, two cups had been poured.

"Let us speak together," said Marla.

"I was afraid," said the voice. "I still am."

"So was I," she said. "So am I still."

"It was an unworthy fear."

"Yes."

"You felt it too?"

"I did."

"Are we the same?"

"Close enough," she said, and she picked up her cup, the warm welcoming scent curling up around her. Across the table, the shadow faded away; but her host remained. Together, they drank their tea.

Laurence Raphael Brothers is a writer and a technologist. His stories have appeared in such venues as Daily Science Fiction, The Sockdolager and the New Haven Review. Follow him on Twitter: @lbrothers 